\title{
MEMÓRIA CULTURAL E IMAGINÁRIO PÓS-COLONIAL: O LUGAR DE LÍLIA MOMPLÉ NA LITERATURA MOÇAMBICANA
}

\begin{abstract}
Anselmo Peres Alós*
Resumo: Na primeira parte deste trabalho, ${ }^{1}$ realiza-se uma reflexão sobre a questão da memória e do imaginário pós-colonial no campo dos estudos literários que se dedicam à compreensão das literaturas lusófonas. Busca-se compreender de que maneira tais investigações podem colaborar para uma descolonização do imaginário nas literaturas das ex-colônias portuguesas, dando particular atenção ao caso da literatura moçambicana. Na segunda parte, realiza-se uma leitura interpretativa do livro Ninguém matou Subura (1988), de autoria da escritora moçambicana Lília Momplé, na tentativa de rastrear as maneiras e os mecanismos discursivos mobilizados pela autora no sentido de transformar as sofridas memórias colonialistas em material para sua composição literária.
\end{abstract}

Palavras-chave: Memória e história; imaginário póscolonial; literatura moçambicana; Lília Momplé; Ninguém matou Subura.

\footnotetext{
* Instituto Superior de Ciências e Tecnologia de Moçambique e Instituto Superior de Comunicação e Imagem de Maputo.

${ }^{1} \mathrm{O}$ presente trabalho é um dos resultados parciais do meu projeto de investigação, intitulado Narrações do inenarrável: a questão da identidade nacional nas literaturas brasileira e moçambicana (iniciado em fevereiro de 2010 e concluído em fevereiro de 2011), desenvolvido sob os auspícios da Embaixada do Brasil em Maputo e do Instituto Superior de Ciências e Tecnologia de Moçambique (ISCTEM).
} 


\section{O comparatismo e as literaturas lusófonas}

Um vislumbre pela história da constituição do comparatismo como campo de investigação nos estudos literários evidencia suas conexões, desde suas origens até as suas tendências contemporâneas, de seus estreitos vínculos com as políticas da produção cultural. Ao longo das últimas décadas, a literatura comparada ramificouse, ampliando seu campo de forma a dar conta das relações entre culturas distintas, bem como dos diferentes extratos culturais de uma mesma comunidade discursiva identificada sob a égide da categoria nação. Nos seus mais recentes desdobramentos, os estudos comparatistas começam a questionar as definições hegemônicas e historicamente consagradas sobre os limites do campo literário, sobre a legitimidade dos discursos teóricos que tomam a literatura como objeto, e sobre o papel do ensino de literatura nas universidades. Na esteira dos estudos contemporâneos de literatura comparada, o caráter apriorístico do discurso literário vem sendo questionado, uma vez que, se a literatura é um discurso resultante de práticas sociais intersubjetivas, sua especificidade não passa de um jogo de convenções cristalizado em determinados momentos históricos. A noção de "literatura nacional" vem sendo avaliada atualmente em seus estritos vínculos com os processos de instauração das "comunidades imaginadas", termo que Benedict Anderson utilizou para descrever os processos históricos de constituição dos nacionalismos europeus no século XVIII em seu livro Nação e consciência nacional (1989). O valor artístico dos artefatos literários, por grande tempo considerado uma qualidade intrínseca aos textos, passa a ser visto como o resultado da interação de fatores intrínsecos $e$ extrínsecos, fatores estes que sempre incluem nuances políticas, refratando os interesses hegemônicos.

A partir do abalo sísmico produzido pelas diversas correntes do pensamento contemporâneo, a teoria literária passou a questionar e bistoricizar a genealogia de suas próprias categorias de análise, 
e a pretensão ao universalismo vem sendo abandonada em nome de uma reflexão sobre as condições históricas e contextuais em que seu próprio discurso é formulado. Tais considerações não implicam no abandono da especificidade da literatura frente a outras práticas discursivas, mas em um redimensionamento do seu funcionamento na esfera da cultura, o qual ultrapassa os limites da fruição estética. É neste contexto que os estudos literários ganham uma relevância estratégica como campo de conhecimento. Tal como afirma Mary-Louise Pratt, ${ }^{2}$ é fundamental que os estudos de literatura comparada sejam reconfigurados como lugar de renovação e intervenção intelectual no estudo da literatura e da cultura. Em tempos de diásporas e exílios transnacionais de escala planetária, produzidos por um sem-fim de conflitos étnico-raciais, pela intolerância religiosa e pelos novos fundamentalismos, a literatura comparada transforma-se em um espaço particularmente profícuo para o cultivo do multilinguismo, da mediação cultural e consciência planetária, possibilitando a imaginação de novas formas de cidadania em um mundo globalizado.

Tais reflexões são de particular relevo quando o objeto de estudo em questão são os textos literários produzidos em Angola, Cabo Verde, Moçambique e Timor Leste, países que até 1975 estavam sob o domínio colonial português. Enquanto os países europeus constituíram suas identidades nacionais em fins do século XVII e inícios do XIX, e grande parte das nações americanas já havia consolidado seus projetos nacionalistas em fins do século $\mathrm{XIX}$, cabe lembrar que em muitas das nações lusófonas o processo de constituição de identidades nacionais através do discurso literário inicia-se apenas ao final do século XX. É de sintomática importância, por exemplo, o ano de 1999: de um lado, a União Européia adota uma moeda única, em sintonia com os processos de globalização da economia e da circulação do capital (inclusive cultural); de outro, o Timor Leste, depois de mais de vinte anos de

${ }^{2}$ PRATT. Comparative literature and global citizenship, p. 58-65. 
ocupação indonésia, finalmente alcança sua independência política. Estar-se-ia vivendo um período de "globalização do imaginário", correlativo à globalização do capital econômico e das relações internacionais? Ou será que a literatura, na contramão da globalização econômica do planeta, estaria a funcionar como um processo simbólico e discursivo que, a contrapelo da homogeneização cultural, insiste no caráter irredutível da diferença como capital cultural fundamental na economia das relações humanas?

Dois romances portugueses recentes (publicados em 2008, mas que apenas agora começam a reverberar nas discussões literárias) merecem ser aqui mencionados. São eles $A$ batalba das lágrimas, de Joana Ruas, e O último ano em Luanda, de Tiago Rebelo. No primeiro, a autora escreve um longo romance histórico ambientado no Timor Leste, que cobre o período entre 1870 e 1910, período entre os acontecimentos decorrentes do Ultimato Britânico e o fim da Monarquia em Portugal; no segundo, Rebelo narra os acontecimentos que tiveram lugar entre 25 de abril de 1974 e o dia da Independência de Angola (11 de novembro de 1975). Enquanto a narrativa de Joana Ruas sensibilizou leitores portugueses e timorenses em função da textualização de um importante período da história do país, Tiago Rebelo, por sua vez, despertou a ira dos leitores angolanos (e de alguns portugueses) em função da perspectiva neo-colonialista que atravessa as páginas do referido romance.

Estes fatos colocam em relevo novas e instigantes questões: se de um lado é possível afirmar que a expressão literária nos países africanos lusófonos já alcançou uma substanciosa autonomia frente aos postulados estéticos eurocêntricos, de outro cabe lembrar que alguns escritores portugueses também estão a repensar os processos históricos que levaram à independência das ex-colônias portuguesas. Por fim, à exceção dos romances de Luís Cardoso e dos poemas de Xanana Gusmão, as letras timorenses permanecem praticamente desconhecidas do público leitor brasileiro e português. Tais fatos levantam pontos fulcrais - 
quando não peremptórios - para uma melhor compreensão da produção literária contemporânea nas nações lusófonas. Quais são os recursos que estão sendo mobilizados na formulação e reformulação das memórias, das imagens e dos símbolos culturais - via literatura - ligados aos acontecimentos históricos que levaram ao fim do colonialismo português, por parte dos escritores angolanos, moçambicanos, cabo-verdianos e timorenses? No sentido inverso, mas igualmente relevante, quais são as memórias, imagens e símbolos que estão sendo articulados no romance português contemporâneo face às relações políticas do passado entre Portugal e os outrora denominados territórios ultramarinos? Que tipo de mudança no imaginário social está sendo proposta pelo romance contemporâneo no que tange às imagens e miragens produzidas sobre Angola, Moçambique, Cabo Verde e Timor Leste? Quais as soluções estéticas e formais encontradas pelos escritores lusófonos africanos e asiáticos para levar a cabo este processo de caráter dialético entre o próprio e o alheio? Dito de outra maneira, como se cristalizam, nos textos literários, o resultado do embate colonial entre o imaginário europeu e os imaginários autóctones? Haveria alguma espécie de síntese dialética ou, ao contrário, estas obras mostrariam uma convivência violenta - com resultados heterogêneos - entre cosmovisões eurocêntricas e autóctones? Quais são as constantes imagéticas que se mostrariam, então, como dominantes na estruturação das constelações simbólicas pertencentes ao que poderia ser chamado, provisoriamente, de "imaginário pós-colonial lusófono"?

Resgatar o compromisso da crítica literária e cultural com o embate de idéias e com a problematização da cultura própria e da cultura alheia é uma questão estratégica neste sombrio iniciar de século, o qual ameaça as culturas minoritárias e/ou subalternizadas com a instrumentalização do ensino de línguas estrangeiras. É esquecido o fato de que, agregada à língua do outro (e, por extensão, à literatura do outro), está uma cultura e um sistema conceitual que não pode ser negligenciado a partir de uma 
compreensão rasa dos processos de tradução cultural. Sob o mito da transparência dos processos de tradução cultural, esconde-se uma lógica perversa que obnubila as diferenças. Se é verdade que todo processo de tradução cultural implica em uma perda e em um ganho, cumpre restituir a importância de se potencializar os ganhos e minimizar as perdas através do reconhecimento das alteridades.

O escritor moçambicano Mia Couto, talvez um dos mais representativos romancistas da África lusófona contemporânea, ao lado de outros como Germano Almeida (Cabo Verde) e Pepetela e José Eduardo Agualusa (Angola), é reconhecido pela crítica em função do talento inventivo que expressa em seus escritos, que vai desde o nível lexical, com a criação de neologismos inspirados nos usos populares da língua portuguesa em Moçambique, até a fabulação de universos que beiram o realismo mágico, como no romance $O$ último vôo do flamingo (2004). Cabe salientar, entretanto, que não é apenas o apelo poético dos escritos de Mia Couto que chama a atenção de seus leitores e críticos mundo afora. $O$ poder de subversão cifrada através das imagens poéticas narradas nas histórias de Mia Couto extrapola os domínios da norma culta da língua portuguesa. Por detrás das inúmeras metáforas e neologismos, há um profundo senso de intervenção política a marcar a obra do escritor moçambicano, tal como ele mesmo afirma:

estou a falar e escrever em um momento em que a nossa democracia, que é uma conquista de todos nós, está a ser posta em causa todos os dias, e está ser posta em causa gravemente por ameaças de violência, por comportamentos profundamente antidemocráticos. ${ }^{3}$

Perdida entre o passado colonial e uma abertura à promessa da modernização que, contudo, nunca chega, Vila

\footnotetext{
${ }^{3}$ COUTO. Entrevista, p. 1.
} 
Cacimba (espaço no qual transcorre a ação do romance Venenos de Deus, remédios do diabo, também de Mia Couto) passa a ser um pouco mais do que o local de convívio de personagens que vivem de suas pequenas mentiras e de seus farrapos de memórias. Vila Cacimba, heterotopia ${ }^{4}$ narrada pelo autor, é um daqueles espaços nos quais as geografias são entrelaçadas e as histórias sobrepostas, metáfora sugerida por Edward Said (em seu livro Cultura e imperialismo) para que se compreenda a multiplicidade do tempo social nas nações pós-coloniais. Entre a amnésia histórica e as genealogias imaginadas a explicar o presente, talvez não reste mais metafísica para além dos beijos-da-mulata, as flores brancas do esquecimento espalhadas pela misteriosa mensageira de vestido cinza a errar entre as névoas de Vila Cacimba. Metáfora ambígua, mas inteligível: o semear das flores do esquecimento, ao final do romance, traduz os riscos do apagamento desta bistória de entremeio. Uma história bastante conhecida por parte daqueles que sobreviveram às violências colonialistas de Portugal, e que se sentem, neste admirável mundo novo do terceiro milênio, ${ }^{5}$ tal qual Sidónio Rosa, o protagonista do romance, condenados a um exílio da alma, do qual não há retorno possível.

Com esta breve menção a um dos autores moçambicanos mais conhecidos fora de seu país, pode-se observar por que a textualização da memória e do imaginário pós-colonial tem ganhado um papel de destaque na produção literária lusófona contemporânea. Tal como afirma Homi Bhabha:

o presente não pode mais ser encarado simplesmente como uma ruptura ou um vínculo com o passado e o futuro, não mais uma presença sincrônica: nossa autopresença mais imediata, nossa imagem pública, é revelada por suas descontinuidades, suas desigualdades, suas minorias. ${ }^{6}$

\footnotetext{
${ }^{4}$ FOUCAULT. Ditos e escritos, v. III, p. 415.

${ }^{5}$ SCHMIDT. A literatura comparada nesse admirável mundo novo, p. 11-33.

${ }^{6}$ BHABHA. O local da cultura, p. 23.
} 


\section{Narratologia, comparatismo e imaginários pós-coloniais}

O desafio intelectual colocado pelos movimentos históricos de lutas de independência e de direitos civis na década de 60, denunciando a ficção emancipatória da modernidade expondo o racismo, o sexismo e o imperialismo subjacentes à política de edificação da cultura moderna no Ocidente, intensificou avanços teóricos dentro de um processo que poderia se chamar de descolonização do conhecimento. ${ }^{7}$ Entende-se aqui, por colonialismo, a permanência residual de mecanismos coloniais através de ajustes e transformações que permitem a sua reintegração e efetiva ação em um mundo em transformação. Isso significa dizer que a continuidade imperial no presente depende da dinâmica de variações de seu poder significativo como forma de atualizar-se e, assim, manter seu domínio. As perspectivas póscoloniais dirigem o olhar do intelectual rumo a um questionamento das limitações geridas pelos consensos culturais e simbólicos, forçando à relativização e reformulação de categorias-chave do humanismo, tais como as de progresso e civilização, particularmente caras ao pensamento ocidental e às (meta)narrativas da modernidade.

A compreensão e a produção de conhecimento não são operações que podem ser efetivadas a partir de uma performance exclusivamente instrumental. É necessário um movimento dialético que articule a reflexão crítica aos conceitos; é necessária também uma reflexão crítica sobre os próprios conceitos em questão. Apropriar-se da narratologia de uma forma meramente

\footnotetext{
${ }^{7}$ Uso aqui esta expressão em analogia ao título do livro Decolonizing the mind (1986), do escritor queniano Ngugi Wa Thiong'o, o qual renunciou à língua inglesa, ao cristianismo e ao seu próprio nome civil (James Ngugi), considerando-os um legado advindo das heranças colonialistas em seu país. Ngugi Wa Thiong'o passa então a escrever em kikuyu, sua língua materna, e em 1980 publica Caitani mutharaba ini [O diabo sobre a cruz], o primeiro romance moderno publicado em kikuyu, o qual foi, alguns anos depois, traduzido para o inglês.
} 
instrumentalista é recair na ilusão iluminista de que é possível ao sujeito da análise posicionar-se fora daquilo que está sendo estudado. Esta afirmativa não chega a configurar uma novidade dentro dos estudos da narrativa. Tzvetan Todorov, em Estruturalismo e poética, faz a seguinte afirmação: "será necessário lembrar que, desde Kant, não se ignora mais que é o método que cria o objeto, que o objeto de uma ciência não está dado na Natureza, mas representa o resultado de uma elaboração?". ${ }^{8}$ A partir do momento em que se cai nessa ilusão (a da neutralidade do discurso científico), o papel do intelectual fica restrito a uma descrição baseada em categorias pré-estabelecidas, o que, em última análise, não produz conhecimento crítico sobre o objeto em questão. Mieke Bal, por sua vez, condena veementemente a utilização do método narratológico como um simples "classificador de textos", pois a compreensão de um texto narrativo envolve muito mais do que a sua classificação em categorias pré-estabelecidas:

Classifying texts as a method of analysis, therefore, is a circular way of reasoning. There is no direct logical connection between classifying and understanding texts. And understanding - if taken in a broad sense that encompasses cognition as well as affective acts, precisely, not distinguished $-i s$ the point. ${ }^{9}$

De acordo com Gilbert Durand, o homem é dotado de uma significativa faculdade simbolizadora no que diz respeito à vida sócio-cultural. Para possibilitar a interpretação dos símbolos e as imagens que se emergem das profundezas do inconsciente coletivo, o autor propõe uma abrangente classificação taxionômica das imagens do sistema antropológico, criando uma espécie de "atlas" arquetipológico da imaginação simbólica. As bases fundacionais da produção do imaginário são fundamentais na vida

${ }^{8}$ TODOROV, T. Estruturalismo e poética, p. 18.

${ }^{9}$ BAL. Narratology, p. 221. 
social e cultural. Em outras palavras, os regimes de imagens e suas configurações simbólicas possuem uma importante função de mediação no que tange à percepção humana da realidade social e na estruturação do psiquismo humano. Na esteira da hermenêutica existencial fenomenológica, a mitocrítica considera o sujeito uma parte integrante na configuração da realidade, o que significa que esta é apreendida pelo sujeito como manifestação. Dito de outra maneira, o homem, através da imaginação simbólica, é tomado como um dos elementos estruturantes da realidade que lhe é exterior.

Se "o mito já é um esboço de racionalização, dado que utiliza o fio do discurso, no qual os símbolos se resolvem em palavras e os arquétipos em idéias", ${ }^{10}$ cabe salientar que o embate colonialista no mundo lusófono, ao impor aos povos africanos e asiáticos a adoção de uma epistème calcada nos primados eurocêntricos e a refutação das cosmogonias autóctones, gerou um processo de recalcamento do imaginário durante o período colonialista. Durand ainda salienta que:

Em cada fase histórica a imaginação encontra-se presente inteira, numa dupla e antagonista motivação: pedagogia da imitação, do imperialismo das imagens e dos arquétipos tolerados pela ambiência social, mas também fantasias adversas da revolta devidas ao recalcamento deste ou daquele regime de imagem pelo meio e o momento histórico. ${ }^{11}$

Logo, é de se supor que o advento da independência política das ex-colônias portuguesas possibilitou a reestruturação da imaginação simbólica desses povos, na medida em que uma espécie de "retorno do recalcado" torna-se possível após o término da dominação política e simbólica exercida pelos portugueses. As

\footnotetext{
${ }^{10}$ DURAND. As estruturas antropológicas do imaginário, p. 63.

${ }^{11}$ DURAND. As estruturas antropológicas do imaginário, p. 390.
} 
maneiras de "ser no mundo", bem como as de se compreender questões tais como a infância, os significados da masculinidade e da feminilidade, as modalidades de institucionalização das identidades coletivas e as projeções metafóricas e metonímicas dos mitos e imagens do heroísmo e outros valores humanos - é de se supor - passam por uma profunda re-acomodação, de maneira a reestruturar as constelações simbólicas que regem a vida social e a criação literária nestes territórios nacionais.

Todavia, os estudos pós-coloniais, os quais logram alcançar institucionalização e reconhecimento acadêmico nos fins do século $\mathrm{XX}$, têm demonstrado que a lógica que permeia a produção, a manutenção e a subversão dos sistemas culturais nos regimes colonialistas e imperialistas é mais complexa do que possa parecer à primeira vista. Edward Said, em Orientalismo (1995), demonstra como um campo de conhecimento estrutura uma forma de apreender grandes extensões territoriais, subordinando um ato de reducionismo epistemológico aos interesses de manipulação política e econômica dos grandes impérios europeus sobre o Oriente. É nas primeiras páginas de Cultura e Imperialismo, entretanto, que o pensamento de Said vem ao encontro das reflexões que aqui são tecidas, quando afirma que:

o contato imperial [poder-se-ia ler aqui colonialista] nunca consistiu na relação entre um ativo intruso ocidental contra um nativo não ocidental inerte e passivo; sempre houve algum tipo de resistência ativa e, na maioria esmagadora dos casos, essa resistência acabou preponderando. $^{12}$

Cabe, pois, perguntar: de que maneiras, e até que ponto, a narrativa literária cumpre o papel de locus e media de articulação de estratégias de resistência simbólica nas ex-colônias portuguesas? Estariam as literaturas lusófonas da Ásia e da África restritas à

${ }^{12}$ SAID. Cultura e imperialismo, p. 12; colchetes nossos. 
reprodução do imaginário europeu em função da condição de colonialismo à qual estavam submetidas? Ou será que, em função de certa liberdade inerente à atividade artística (e, particularmente, à escrita literária e imaginativa), os escritores puderam expropriar o colonizador e projetar sua própria identidade a partir de processos de dessacralização e ressacralização mítica das imagens e símbolos estruturados na imaginação literária?

\section{Um caso pontual: os contos de Lília Momplé}

Lília Maria Clara Carrière Momplé nasceu em 19 de Março de 1935, na mítica Ilha de Moçambique, localizada ao norte do país, na província de Nampula. Concluiu seus estudos secundários na capital da colônia, na cidade de Lourenço Marques (hoje Maputo). Na universidade, frequentou durante dois anos o curso de Filologia Germânica, deixando-o para formar-se em Serviço Social no Instituto Superior de Serviço Social de Lisboa. Depois de uma temporada na Grã-Bretanha (durante 1964) e de outra no Brasil (de 1968 a 1971), a escritora regressa definitivamente a Moçambique no ano de 1972. Encerrados os seus estudos em Lisboa, Lília Momplé trabalhou como funcionária da Secretaria de Estado da Cultura, como diretora do Fundo para o Desenvolvimento Artístico e Cultural de Moçambique, e como Secretária-Geral da Associação de Escritores de Moçambique (AEMO), durante o período de 1995 a 2001. De 1997 a 2001, acumulou, juntamente com a função de Secretária-Geral da AEMO, a função de Presidente da instituição. Durante o período em que esteve na presidência da associação, não mediu esforços para aumentar a visibilidade das mulheres nas publicações da instituição. Foi também representante do Conselho Executivo da UNESCO, no período compreendido entre 2001 e 2005. Apesar de suas colaborações dispersas na imprensa, Lília Momplé destaca-se no cenário da literatura moçambicana por seus três livros: Ninguém matou Subura (contos, 1988), Neigbbours (romance, 1996) e Os olbos da cobra 
verde (contos, 1997). Em 2001, foi agraciada com o Prêmio Caine para Escritores de África, com o conto "O baile de Celina". Além deste prêmio, recebeu também o $1^{\circ}$ Prêmio de Novelística no Concurso Literário do Centenário da Cidade de Maputo, com o conto "Caniço".

Ninguém matou Subura é um livro de contos composto de maneira singular. As cinco narrativas que o compõe podem ser lidas de maneira independente, mas, ao mesmo tempo, estão interconectadas de maneira temática, através da representação e da denúncia da violenta experiência colonial dos povos de Moçambique e Angola ao longo do século XX. Cada um dos contos retrata um aspecto singular do colonialismo português em África, cobrindo uma linha temporal que se estende de 1935 a 1974. Cada um dos contos inicia com uma data precisa e, à exceção de "Aconteceu em Saua-Saua" (narrativa que abre o livro), cada um deles emerge do universo retratado pela escritora com uma demarcação geográfica precisa, indicando-se a cidade na qual os eventos narrados se desenrolam. Embora seja possível depreender, pela ambientação deste último conto, que sua referência espacial seja, supostamente, o regulado ${ }^{13}$ de Saua-Saua, o fato da indicação não constar no início da narrativa (mais a impossibilidade de se localizar este regulado nos mapas contemporâneos de Moçambique), faz com que a afirmação precisa sobre sua localização geográfica seja imprecisa e indeterminável.

\footnotetext{
${ }^{13}$ Um regulado é uma pequena aldeia tradicional, parte da organização social das coletividades moçambicanas no período pré-colonial. O nome pelo qual se designa tal povoamento advém de seu líder político, o régulo (significando, literalmente, "pequeno rei”). Em função da exploração colonialista em Moçambique e da destruição de inúmeros regulados durante o período colonialista e das guerras civis que se seguiram à independência, é praticamente impossível precisar se Saua-Saua é um regulado com um referente "real" ou uma projeção imaginativa que, por metonímia, representaria o modus operandi das relações travadas entre as administrações colonialistas portuguesas e as comunidades autóctones de Moçambique durante as primeiras décadas de exploração lusitana no século XX.
} 
À exceção da última narrativa, intitulada "O último pesadelo", a qual se passa em Luanda, todos os outros contos estão ambientados em Lourenço Marques (a antiga capital colonial que, após a independência moçambicana, em 1975, passa a chamar-se Maputo e torna-se a capital do país) ou na Ilha de Moçambique (terra natal da escritora). Em todos os contos, a autora adota um narrador em terceira pessoa, onisciente, e a focalização narrativa oscila entre a focalização interna (na qual a voz narrativa tem acesso aos pensamentos e ao universo interior das personagens) e a narrativa externa (na qual, a partir de um locus exterior ao universo diegético instaurado pelos eventos narrados, a voz narrativa emite seus juízos e comentários acerca dos eventos que vão sendo apresentados ao leitor). É mister ressaltar que esta técnica narrativa é uma constante ao longo de todas as obras de Lília Momplé.

Em "Aconteceu em Saua-Saua”, narra-se a trágica experiência de Mussa Racua, humilde camponês recrutado pela administração colonial para cultivar arroz. A administração colonial, arbitrariamente, demarcava as terras a serem cultivadas e distribuía as sementes, estabelecendo também as metas de produtividade agrícola. Caso o camponês em questão não alcançasse a meta, corria o risco de ser recrutado, em nome do pagamento da "dívida”, para trabalhar nos campos de sisal. É esta a situação na qual se encontra Mussa Racua, que desesperadamente tenta pedir a seus vizinhos dois sacos de arroz para completar a sua cota de produção:

- Mas tu já viste, irmão, que vida é a nossa? - interrompe Mussa Racua - vem essa gente da Administração e marcate um terreno. Dão-te sementes que não pediste e dizem: tens que tirar daqui três ou seis ou sete sacos, conforme lhes dá na cabeça. E se por qualquer razão adoecemos ou não cai chuva ou a semente é ruim, e não conseguimos entregar o arroz que eles querem, lá vamos nós parar às plantações. E os donos das plantações ficam contentes porque conseguem uma data de homens para trabalhar de graça. $\mathrm{E}$ a gente da Administração fica contente porque 
recebe dos donos das plantações um tanto por cabeça que entrega. E nós é que vamos rebentando de medo e de trabalho todos os anos. E mal podemos cuidar das nossas machambas que nem dão para comer. ${ }^{14}$

A preocupação de Mussa Racua em cumprir com a cota estabelecida pela administração colonial não surge em vão. Ele já experienciara na própria pele as agruras do trabalho nas plantações de sisal. Frente ao desespero, Mussa Racua divide com o amigo Abudo as amargas recordações do trabalho nos campos:

- Escuta! - continua Mussa Racua, numa exaltação febril - eu nunca te falei daquele sofrimento. Todos os que experimentaram a plantação não querem mais falar daquilo. A comida sabe a merda! E mesmo assim é só o suficiente para um homem agüentar o trabalho. E aquele sisal que nunca mais acaba. Aquele sisal tem sangue, irmão, está cheio de sangue! A trabalhar sempre doente. Doente e a apanhar porrada. E depois de tanto tempo, vir de lá sem nada... Sem nada, irmão! ${ }^{15}$

Como se já não fosse suficiente a temporada de trabalhos forçados em condições precárias e sem remuneração nenhuma, depois de sua primeira temporada nos campos de sisal Mussa Racua, ao regressar para a aldeia de Saua-Saua, descobre que sua humilde palhota de camponês foi saqueada e seus poucos pertences roubados, assim como os poucos cabritos que possuía. A esposa também o abandona, pois "não aguentara a longa ausência, sem notícias e sem dinheiro". ${ }^{16}$ Tais recordações o deixam aflito e o inevitável medo de perder a segunda esposa em uma nova temporada de trabalhos forçados na plantação de sisal leva Mussa Racua a uma decisão desesperada: no meio da noite, abandona

\footnotetext{
${ }^{14}$ MOMPLÉ. Aconteceu em Saua-Saua. In: Ninguém matou Subura, p. 12-13.

${ }^{15}$ MOMPLÉ. Aconteceu em Saua-Saua. In: Ninguém matou Subura, p. 13.

${ }^{16}$ MOMPLÉ. Aconteceu em Saua-Saua. In: Ninguém matou Subura, p. 17.
} 
sua palhota e suicida-se, enforcando-se com o auxílio de uma corda, em um dos galhos de uma frondosa mangueira à beira da estrada. O administrador colonial da aldeia, após ouvir o relato, contado em língua macua por um senhor transeunte ao Língua (o tradutor local do administrador), expressa sua raiva e impaciência: “- Estes cães assim que lhes cheira a trabalho, arranjam sempre chatices. Ou fogem ou suicidam-se. Maldita raça!". ${ }^{17}$

A grande ironia do conto está no seu encerramento, o qual desvela a violência colonialista e o racismo a ela subjacente, através das palavras do administrador. Após o relato da trajetória de Mussa Racua, a voz narrativa pode isentar-se de manifestar seu posicionamento frente à atitude desesperada do protagonista. Desfralda-se assim, a partir do gesto suicida do protagonista, a denúncia da experiência colonial, e o leitor é conduzido a interpretar a autodestruição do protagonista como a única atitude de resistência possível. As palavras do administrador, por sua vez, não marcam apenas a indiferença do mesmo com as populações autóctones de Moçambique. O gesto de resistência anti-colonialista de Mussa Racua, ao ser lido e interpretado como preguiça e indolência por parte do administrador, é destituído de seu estatuto de resistência. $\mathrm{O}$ administrador vilipendia simbolicamente o cadáver do protagonista, roubando o sentido de seu gesto desesperado: ao invés de marcar o espaço simbólico como um germe de resistência, da única resistência possível às arbitrariedades daquele momento histórico, o significado da ação autodestrutiva de Mussa Racua é rasurado e apagado pela epistème colonialista.

O conto "Caniço" traz à memória do leitor, já em seu título, as reverberações dos "bairros de caniço", aglomerados de pequenas palhotas construídas com caniço e, por vezes, cobertos com folhas de coqueiro, nos quais residiam as populações negras mais humildes, espoliadas pelo jugo colonialista, e que se localizam,

\footnotetext{
${ }^{17}$ MOMPLÉ. Aconteceu em Saua-Saua. In: Ninguém matou Subura, p. 21.
} 
em grande quantidade, ainda hoje, nos arredores mais distantes da antiga capital colonial, Lourenço Marques. Cronologicamente situado no ano de 1945, a narrativa inicia apresentando a história da família do jovem Naftal, que ainda criança perde o pai, em função de uma tuberculose contraída nas profundezas das minas da África do Sul, onde trabalhava. Com a morte do pai, a situação de pobreza da família agrava-se, e Aidinha, a irmã mais velha de Naftal, cansada da vida miserável que leva com a família no bairro de caniço, acaba entregando-se à prostituição. A mãe, ao descobrir o destino de Aidinha, tenta resgatá-la:

- Vamos para casa, minha filha.

Aidinha não lhe disse que está farta da miséria e que sendo negra, não tinha outro caminho para se livrar dela. Só tornando-se puta. Não disse nada disso, mas respondeu com a fria serenidade de quem há muito tinha feito uma opção:

- Não, mãe, deixe-me viver assim. Para a palhota eu não volto mais. Nunca mais. ${ }^{18}$

Para ajudar a família, o jovem Naftal começa a trabalhar como empregado doméstico junto a uma família de brancos, na parte rica da cidade. Tudo corre bem até o dia em que desaparece o relógio de ouro de sua patroa: "Ouve lá, Naftal, não viste meu relógio de ouro?". ${ }^{19}$ Naftal entra em pânico, pois sabe que tipo de acusação está subliminarmente presente nessas palavras. Ao fim do dia, quando o patrão chega, ele e o cozinheiro da casa são levados à esquadra policial, e o patrão encarrega a polícia colonial de resolver a questão. Quando o patrão chega à casa, sua esposa já havia resolvido o mistério: sua filha, Mila, havia encontrado o relógio no banheiro, e decidiu o levar à escola, para impressionar as colegas. Todavia, mesmo com o mistério resolvido, o patrão se

${ }^{18}$ MOMPLÉ. Caniço. In: Ninguém matou Subura, p. 28.

${ }^{19}$ MOMPLÉ. Caniço. In: Ninguém matou Subura, p. 34. 
nega a ir até a esquadra para esclarecer o mal-entendido: "A queixa já está lá, não podemos voltar atrás. Deixa-os lá apanhar. É pelas vezes que nos roubam e não são descobertos". ${ }^{20}$ A partir de uma cena aparentemente banal, a voz narrativa explicita o clima de desconfiança e bestialização da população negra frente ao racismo dos colonos portugueses. Naftal, por sua vez, é retratado ao longo do conto de maneira a enfatizar sua agonística existencial: mesmo sendo um trabalhador honesto e dedicado, o colonialismo racista coloca todos os autóctones sob a suspeita dos "instintos roubadores" dos moçambicanos.

Já em "O baile de Celina”, conto que se passa em 1950, retrata-se a dolorosa experiência de Celina, jovem aluna do Liceu Salazar, que está prestes a se formar. Embora filha de uma família de poucas posses, Celina tem uma vantagem: sua mãe é modista, o que lhe permitiu não apenas estudar no Liceu dos brancos, como também lhe possibilitou ter um vestido vaporoso e elegante para a celebração do fim de seus estudos. Entretanto, chegadas as vésperas do baile, Celina é chamada pelo diretor da instituição e proibida de participar do baile de finalistas, por ser negra. Indignada com o fato, retorna a casa, senta-se em sua cama e, com uma tesoura, picota o vestido, em meio às lágrimas oriundas da frustração de não poder participar do baile. ${ }^{21}$

"Ninguém matou Suhura" - conto que dá título ao livro é, talvez, o que mais explicitamente denuncie as arbitrariedades do colonialismo português em terras moçambicanas. Na primeira parte do conto, relata-se o dia do Senhor Administrador, que mantém

\footnotetext{
${ }^{20}$ MOMPLÉ. Caniço. In: Ninguém matou Subura, p. 35.

${ }^{21}$ Em entrevista recente, retransmitida pelo canal TVM de Moçambique em função do falecimento do fotógrafo moçambicano Ricardo Rangel (figura pública muito próxima de Lília Momplé), o mesmo afirmou que este conto é fortemente autobiográfico e que a situação enfrentada pela personagem Celina foi inspirada em uma situação semelhante, vivenciada por Lília Momplé em Lourenço Marques.
} 
uma garçonière em uma região afastada da cidade, para a qual leva as garotas virgens que frequentemente encontra pelas ruas, no intuito de violentá-las. Na segunda parte, conta-se o quotidiano de Suhura, uma jovem humilde que mora com a avó e que termina sua tarde sendo escolhida pelo Senhor Administrador em dos seus passeios pelas ruas da Ilha de Moçambique, na província de Nampula, em uma tarde de 1970 . Finalmente, na última parte do conto, relata-se o estupro de Suhura, seguido de seu assassinato por parte do Senhor Administrador, e da entrega do corpo de Suhura à sua avó, que nada pode fazer senão sepultar, em silêncio, o corpo da neta assassinada.

No último conto do livro, intitulado "O último pesadelo" e ambientado em Luanda, no ano de 1974, são apresentados os recorrentes pesadelos de Eugénio, um colono português que viveu durante algum tempo no Hotel Guaraná, na zona da Gabela, onde se encontrava trabalhando como designer para um rico agrimensor local. As tensões geradas pelos conflitos internos entre os colonos portugueses e os militantes do MPLA (Movimento Popular pela Libertação de Angola) fomentam tal grau de desconfiança por parte dos portugueses residentes em Gabela que, em uma dada noite, os hóspedes do Hotel Guaraná reúnem todos os funcionários negros do estabelecimento e os assassinam a pauladas, chutes e pontapés. Eugénio, que nunca escondeu sua simpatia pelo MPLA, é arrastado pelos outros hóspedes do Hotel e obrigado a assistir a carnificina, sendo, em seguida, expulso da Gabela com toda a sua família, tendo de se refugiar em Luanda.

No projeto ficcional de Lília Momplé, torna-se evidente um esforço de vencer a amnésia social, com vistas a manter vivas as recordações das violências e arbitrariedades colonialistas. A beleza de seus contos é diametralmente proporcional à crueza da violência descrita ao longo das páginas de Ninguém matou Subura. É recorrente, em suas narrativas, a presença de uma melancolia histórica, provocada pelo apagamento das agruras da luta pela independência das ex-colônias africanas, e um atento olhar para os desfavorecidos que mais sofreram durante a história moçambicana 
ao longo do século XX. Por trás de personagens como Mussa Racua, Naftal, Aidinha, Celina, Suhura, Eugénio e suas trágicas trajetórias, é possível para o leitor de hoje vislumbrar um pouco da experiência colonial moçambicana através da perspectiva dos sujeitos silenciados e subalternizados ao longo da história recente.

Redimensionar os regimes de representação das comunidades humanas, preocupação comum à Literatura Comparada e aos Estudos Culturais neste início de século, é o primeiro passo para que se construam novas possibilidades de relacionamento no campo social. Em outras palavras, o papel do comparatismo no cenário atual dos estudos literários e culturais pode ser definido como a consolidação de um campo disciplinar e de um saber/poder sobre a diferença cultural. Pleiteia-se, pois, a inserção do objeto literário no campo mais amplo da antropologia, da história, da política e da geografia, contextualizado como prática textual e discursiva que legitima, media e - muitas vezes - subverte os arranjos hegemônicos de poder na esfera cultural.

Em As mil e uma noites, o rei Shariar, louco por haver sido traído por sua primeira esposa, decide-se por deflorar uma virgem diferente todas as noites, assassinado-a na manhã seguinte. Sherazade consegue escapar a esse destino ao contar histórias fantásticas e imaginativas sobre diversos temas que captam a curiosidade do rei. A cada amanhecer, Sherazade interrompe seu conto para continuá-lo na noite seguinte, o que a mantém viva ao longo de várias noites (As mil e uma noites do título da obra), ao fim das quais o rei se arrepende de seu comportamento e desiste de executar Sherazade. Tal como no clássico da literatura árabe, a literatura produzida nas nações lusófonas que apenas recentemente alcançaram a independência política evidencia a importância da modalidade narrativa no seio da cultura: contar histórias (sejam as próprias, sejam as alheias) muitas vezes é a única alternativa para assegurar a sobrevivência da memória neste tempo presente, assombrado pelas promessas auspiciosas de uma "globalização" que, no campo dos direitos humanos, da igualdade e da solidariedade, raras vezes se cumpre. 
Resumen: En la primera parte del presente artículo, se hace una investigación acerca de la cuestión de la memoria y del imaginario postcolonial en el campo de los estudios literarios dedicados a la comprensión de las literaturas lusófonas. Lo que se busca es la comprensión del modo por que esas investigaciones puedan colaborar para una descolonización del imaginario en las literaturas de las ex-colonias portuguesas, con particular atención a la cuestión de la literatura mozambicana. En la segunda parte, se hace una lectura interpretativa del libro Ninguém matou Subura (1988), de autoría de la escritora mozambicana Lília Momplé, intentando rastrear las maneras y los mecanismos discursivos articulados por la autora en el sentido de hacer de sus sufridas memorias colonialistas el material a ser utilizado en su composición literaria.

Palabras-clave: Memoria e historia; imaginario postcolonial; literatura mozambicana; Lília Momplé; Ninguém matou Subura.

\section{Referências}

ANDERSON, B. Nação e consciência nacional. São Paulo: Ática, 1989. BAL, M. Narratology. 2. ed. Buffalo: The University of Toronto Press, 1997. BHABHA, H. K. O local da cultura. Belo Horizonte: Ed. da UFMG, 1998. CARVALHAL, T. F. O próprio e o alheio. São Leopoldo: Ed. da UNISINOS, 2003.

COUTO, M. Estórias abensonhadas. Maputo: AEMO, 1994.

COUTO, M. O último voo do flamingo. Maputo: Ndjira, 2000.

COUTO, M. Entrevista. O país, Maputo, 24 de junho de 2009. Disponível em: < http://opais.co.mz/opais/index.php?option $=$ com content $\&$ view $=$ article $\&$ id $=1786$ : mia-couto-declara-se-num-qvazioqapos-escrever-qjesusalemq $\&$ catid $=82$ : cultura $\&$ Itemid $=278>$. Acesso em: 30 jan. 2011.

COUTO, M. Venenos de Deus, remédios do diabo. Maputo: Ndjira, 2008. 
COUTO, M. Jesusalém. Maputo: Ndjira, 2009.

DURAND, G. As estruturas antropológicas do imaginário. São Paulo: Martins Fontes, 1997.

FOUCAULT, M. Ditos e escritos. Rio de Janeiro: Forense Universitária, 2001. Vol. III.

MOMPLÉ, L. Ninguém matou Subura. Maputo: AEMO, 1988.

MOMPLÉ, L. Ninguém matou Subura. 3. ed. Maputo: Edição da Autora, 2007.

MOMPLÉ, L. Neighbours. Maputo: AEMO, 1995.

MOMPLÉ, L. Os olbos da cobra verde. Maputo: AEMO, 1997.

PRATT, M.-L. Comparative literature and global citizenship. In: BERNHEIMER, C. Comparative literature in the age of multiculturalism. Baltimore: The John Hopkins University Press, 1995. p. 58-65.

REBELO, T. O último ano em Luanda. Barcarena: Presença, 2008.

RUAS, J. A batalha das lágrimas. Coimbra: Calendário, 2008.

SAID, E. Orientalismo. São Paulo: Companhia das Letras, 1990.

SAID, E. Cultura e imperialismo. São Paulo: Companhia das Letras, 1995.

SCHMIDT, R. T. A literatura comparada nesse admirável mundo novo. Revista Brasileira de Literatura Comparada, São Paulo, v. 11, p. 11-33, 2007.

THIONG'O, N. W. Decolonising the mind. Nairobi: Heinemann Kenya, 1986.

THIONG'O, N. W. Devil on the cross. Nairobi: Heinemann Kenya, 1987. TODOROV, T. Estruturalismo e poética. São Paulo: Cultrix, 1970.

Recebido para publicação em 17 de fevereiro de 2011 Aprovado em 30 de junho de 2011 